\title{
CALIBRATION OF StAinless STEEL-EDGED V-NOTCH WEIR STOP LOGS FOR WATER LEVEL CONTROL STRUCTURES
}

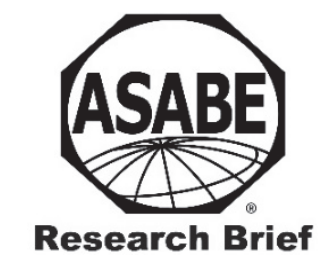

\author{
L. E. Christianson, R. D. Christianson, A. E. Lipka, S. B. Bailey, \\ J. Chandrasoma, C. McCoy, G. Preza Fontes, J. Roh, \\ A. P. Sanchez Bustamante Bailon, N. M. Wickramarathne, R. A. Cooke
}

\begin{abstract}
Dependable flow rate measurements are necessary to calculate flow volumes and resulting nutrient loads from subsurface drainage systems and associated conservation practices. The objectives of this study were (1) to develop appropriate weir equations for a new stainless steel-edged $45^{\circ} \mathrm{V}$-notch weir developed for AgriDrain inline water level control structures and (2) to determine if the equation was independent of flow depth in the structure. Weirs for $15 \mathrm{~cm}(6 \mathrm{in}$.) and $25 \mathrm{~cm}$ (10 in.) inline water level control structures were placed at three heights in each structure: at the base, $48 \mathrm{~cm}$ from the base, or $97 \mathrm{~cm}$ from the base, and the height of the nappe above the weir crest was recorded over a range of flow rates. The resulting data were fitted to equations of the form $Q=a H^{b}$ where $Q$ is the flow rate, $H$ is the height of the nappe above the weir crest, and $a$ and $b$ are fitted parameters. There were no significant differences in the fitted parameters across the two structure sizes or across the three weir placements. The fitted equation for these new stainless steel-edged V-notch weirs was $Q=0.011 H^{2.28}$ with $Q$ in liters per second and $H$ in centimeters, and $Q=1.44 H^{2.28}$, with $Q$ in gallons per minute and $H$ in inches. These equations can be used for measuring flow through AgriDrain in-line structures, although in-house weir calibration is highly recommended for specific applications, when possible.
\end{abstract}

Keywords. Drainage, Flow monitoring, Subsurface drainage, V-notch weir, Weir calibration.

A rtificial subsurface drainage systems are designed to accelerate the removal of excess water from agricultural fields, and in doing so, they also serve as a conduit to move dissolved nutrients, such as nitrate $\left(\mathrm{NO}_{3}^{-}\right)$, from fields (Skaggs and van Schilfgaarde, 1999). Nitrate leaching from agricultural soils is a complex process that depends on many factors such as soil and drainage system characteristics, weather conditions, and management practices (Randall and Goss, 2008). This

\footnotetext{
cC)(1) $\Theta$ The authors have paid for open access for this article. This c. $\mathrm{BY}$ NC ND work is licensed under a Creative Commons AttributionNonCommercial-NoDerivatives 4.0 International License https://creative commons.org/licenses/by-nc-nd/4.0/

Submitted for review in February 2019 as manuscript number NRES 13350; approved for publication as a Research Brief by the Natural Resources \& Environmental Systems Community of ASABE in July 2019.

The authors are Laura E. Christianson, Assistant Professor, Reid D. Christianson, Research Assistant Professor, Alexander E. Lipka, Assistant Professor, Janith Chandrasoma, Graduate Student, Cameron McCoy, Undergraduate Student, Giovani Preza Fontes, Graduate Student, Juhyeon Roh, Undergraduate Student, Ana Paula Sanchez Bustamante Bailon, Graduate Student, Niranga M. Wickramarathne, Graduate Student, Department of Crop Sciences; and Shorma B. Bailey, Graduate Student and Richard A. Cooke, Professor, Department of Agricultural and Biological Engineering; University of Illinois at Urbana-Champaign, Urbana, Illinois. Corresponding author: Laura E. Christianson, AW-101 Turner Hall, MC-046, 1102 South Goodwin Avenue, Urbana, IL 618014730; phone: 217-244-6173; e-mail: LEChris@illinois.edu.
}

complexity limits the ability to model, predict, and manage $\mathrm{NO}_{3}{ }^{-}$leaching (Scharf, 2015). Physically monitoring nutrient losses in drainage water from individual agricultural fields and drained plots is necessary to better understand processes of water and nutrient movement as well as to evaluate the effectiveness of conservation practices such as cover crops, drainage water management, and denitrifying woodchip bioreactors.

Precise and accurate flow rate measurements are necessary to calculate flow volumes and resulting nutrient loads from drainage systems (Chun and Cooke, 2008). A common subsurface drainage monitoring configuration involves use of an AgriDrain inline water level control structure installed on a drainage pipe. These structures operate with flashboard risers (i.e., stop logs) that can be adjusted depending on different management needs and weather conditions (Evans et al., 1995). The rectangular stop logs used in the structures act as a broad-crested weir behind which water depth can be continuously recorded using a pressure transducer. These water depths can be used to calculate the flow rate over the stop log weir using appropriate weir equations depending upon the weir geometry and flow conditions.

Chun and Cooke (2008) developed discharge equations for standard stop logs (i.e., flat crested weirs) for use in AgriDrain inline water level control structures sized for drainage pipes ranging from 15 to $61 \mathrm{~cm}$. For simplicity, 
these structures are referred to as " 15 to $61 \mathrm{~cm}$ control structures" here although this dimension actually refers to the diameter of drainage pipe that is attached to the structure. The equations developed by Chun and Cooke (2008) were differentiated by water depth and flow rate, where a two-parameter equation was used for low flow rates and a one-parameter equation was used for higher flow rates. The equations for $15 \mathrm{~cm}$ structures were:

$$
\begin{gathered}
\mathrm{Q}=0.020(\mathrm{~L}-0.437 \mathrm{H}) \mathrm{H}^{1.48} \quad \mathrm{H} \leq 0.44 \mathrm{~L} \\
\mathrm{Q}=0.027 \mathrm{LH}^{1.2} \quad \mathrm{H}>0.44 \mathrm{~L}
\end{gathered}
$$

where

$\mathrm{Q}=$ flow $\operatorname{rate}(\mathrm{L} / \mathrm{s})$,

$\mathrm{L}=$ width of the control structure stop $\log (\mathrm{cm})$, and

$\mathrm{H}=$ flow depth above the stop $\log (\mathrm{cm})$

And for 20 to $61 \mathrm{~cm}$ structures, the equations were:

$$
\begin{gathered}
\mathrm{Q}=0.020(\mathrm{~L}-0.74 \mathrm{H}) \mathrm{H}^{1.48} \quad \mathrm{H} \leq 0.27 \mathrm{~L} \\
\mathrm{Q}=0.021 \mathrm{LH}^{1.37} \quad \mathrm{H}>0.27 \mathrm{~L}
\end{gathered}
$$

with the symbols similarly defined.

A V-notch weir (or triangular weir) is often preferable for low flow conditions as the change in water depth in the Vshape is relatively greater than over the flat edge of a rectangular weir (Haan et al., 1994; USGS, 1982). The angle of most V-notch weirs ranges from $22.5^{\circ}$ to $90^{\circ}$ with a $90^{\circ}$ angle being the most common (Haan et al., 1994). The basic form of the V-notch weir equation is (USGS, 1982; with units as orginally published):

$$
\mathrm{Q}=1.38(\tan \theta / 2) \mathrm{H}^{(5 / 2)}
$$

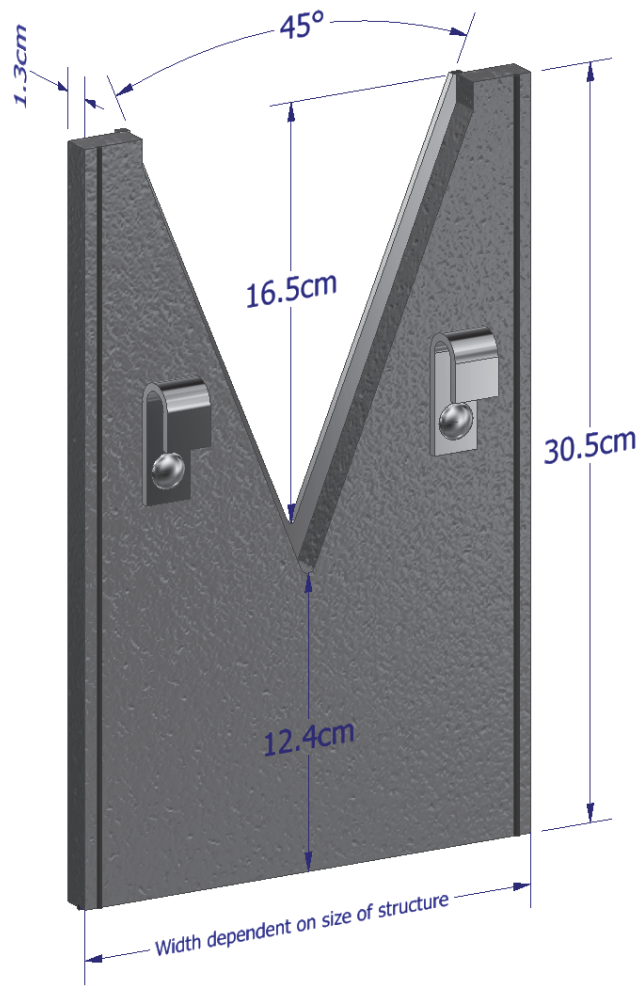

where

$\mathrm{Q}=$ flow rate $\left(\mathrm{m}^{3} / \mathrm{s}\right)$, and

$\mathrm{H}=$ flow depth above the V-notch crest (m).

Cooke (personal communication) developed a form of this equation for plastic V-notch weir stop logs with a $46^{\circ}$ angle and a rounded bottom manufactured for AgriDrain inline water level control structures. AgriDrain provides this equation, typically in U.S. customary units, upon request:

$$
\mathrm{Q}=\mathrm{aH}^{\mathrm{b}}=2.5866 \mathrm{H}^{2.0464}
$$

where

$\mathrm{Q}=$ flow rate (gallons per minute, gpm), and

$\mathrm{H}=$ flow depth above the V-notch crest (in).

An important nuance of weir equations for use in drainage control structures is the height of the weir stop log within the structure. Partheeban (2014) calibrated a standard Vnotch weir stop log within a $15 \mathrm{~cm}$ AgriDrain control structure with the crest placed at 15,32 , and $50 \mathrm{~cm}$ from the bottom of the structure, and reported there was no significant difference in the resulting equations. Their final equation for these conditions was [with units as originally published; valid within the 5 to $153 \mathrm{~L} / \mathrm{min}$ ( 0.083 to $2.5 \mathrm{~L} / \mathrm{s})$ range]:

$$
\mathrm{Q}=1.7406 \mathrm{H}^{1.9531}
$$

where

$\mathrm{Q}=$ flow rate $(\mathrm{L} / \mathrm{min})$, and

$\mathrm{H}=$ height of nappe above the weir crest $(\mathrm{cm})$

In 2018, AgriDrain released a new style of V-notch weir stop $\log$ with a stainless steel front edge (fig. 1) to act as a sharp-crested weir at lower flow depths, thereby improving

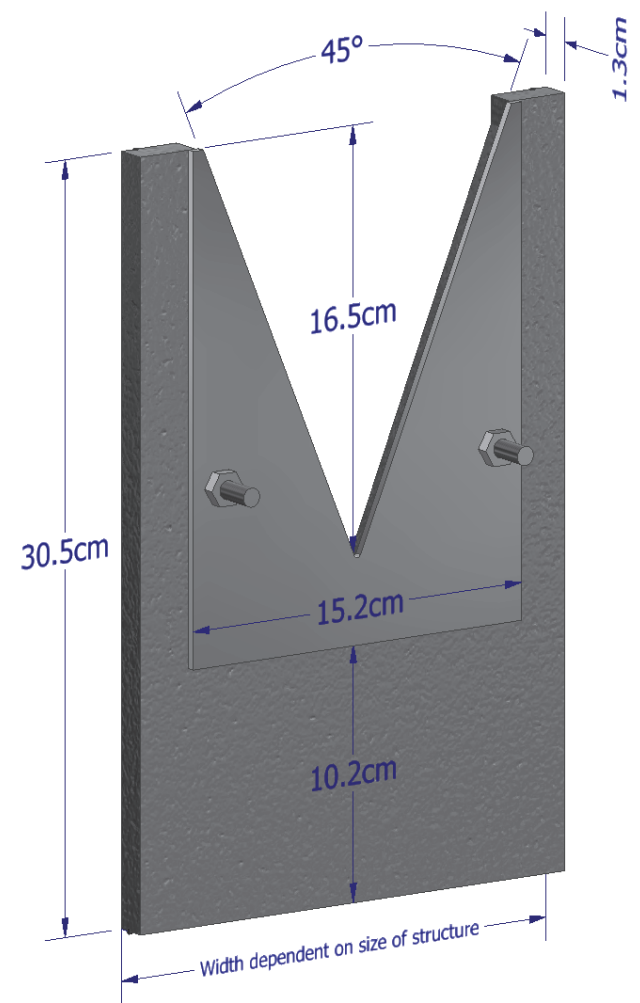

Figure 1. Illustration of the back (left) and front (right) of the new (2018) AgriDrain stainless steel-edged V-notch weir. 
the accuracy of low flow measurements as compared to the wider crested V-notch weir, the equation for which is given in equation 6 . The objectives of this study were (1) to develop appropriate weir equations for these new stainless steel-edged $45^{\circ} \mathrm{V}$-notch weirs for use in AgriDrain control structures and (2) to determine if the equation was independent of flow depth in the structure.

\section{MeTHOdS AND MATERIALS}

Flow equations were developed for V-notch weirs in 15 and $25 \mathrm{~cm}$ inline control structures in the Hydraulics Laboratory in the Department of Agricultural and Biological Engineering at the University of Illinois at Urbana-Champaign. Measurements were made for weirs placed at three depths in each structure (fig. 2): on top of 0,48 , or $97 \mathrm{~cm}$ of stop logs (fig. 2); and the height of the nappe above the weir crest was recorded over a range of flow rates for each placement. Given the $12.4 \mathrm{~cm}$ below the crest on the weir stop log plate (fig. 1), these weir placements equated to 12.4, 60, and 109 $\mathrm{cm}$ from the bottom of the structure to the $\mathrm{V}$-notch crest. The majority of the nape heights were greater than $3 \mathrm{~cm}$ to limit impacts from surface tension (Novak and Cabelka, 1981).

Water heights were measured in a clear PVC stilling well on the outside of each structure to reduce the effect of water level fluctuation in the structures (fig 2). Heights in the stilling well were measured manually to the nearest millimeter using a tape measure attached to the control structure. Flow rates were determined by measuring the time required to collect specified volumes of water in a bucket at low flow rates (flow rates up to $0.4 \mathrm{~L} / \mathrm{s}$ ) and by measuring the time required to collect specified weight of water in a tank mounted on a load cell

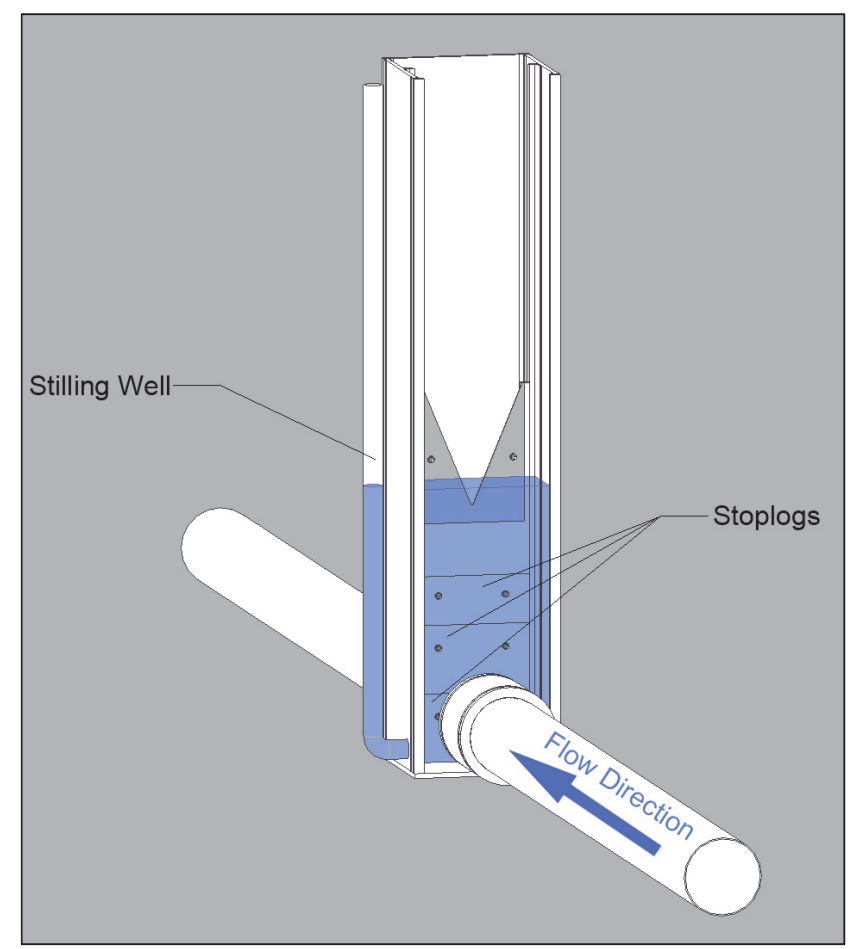

Figure 2. Stop log weir calibration set-up showing weir placement and the stilling well. for high flows. Sample time was measured to the nearest second using a stopwatch with sample volumes of $0.70,1.3,4.6$, and $22 \mathrm{~L}$, depending on the flow rate with sampling times averaging approximately $90 \mathrm{~s}$ for the low flows. The automated load cell measurement times averaged just under $60 \mathrm{~s}$. Triplicate measurements of depth and flow were made for each flow rate at each of the six unique combinations of weir height and control structure size.

Curve fitting was done using an unweighted least squares approach where the sum of the squared error between the measured values and predicted values was minimized. Other fitting techniques such as reciprocal $y$-weighted least squares approach and implementing a log-log transformation were evaluated, but these tended to under predict flow at the highest flow rates. The triplicate readings for each flow rate at each weir elevation/structure size combination were used to statistically compare the relationships created for each weir size/placement combination. That is, each test of a given weir size/placement combination (i.e., a treatment) resulted in three weir equations, the parameters for which were compared across treatments. Treatments were compared using analysis of variance testing in Sigma Plot 14.0 ( $a=0.05$; Systat Software, San Jose, Calif.). All assumptions of data normality and equal variance were met (Shapiro-Wilk and Brown-Forsythe tests, respectively).

\section{RESULTS AND DISCUSSSION}

There were no significant differences when the weir equation parameters were compared across the two structure sizes or across the three weir placements (tables 1 and 2; fig. 3). For example, when equations were developed for the $15 \mathrm{~cm}$ structure for each weir height placement, those parameters were not statistically significantly different between the placements (table 1: parameter a: $p=0.126$; parameter b: $p=0.457)$. Likewise, when the same weir height placement was compared across the two structure sizes, those resulting equation parameters were not statistically significantly different. For example, with the V-notch weir stop log was placed at the structure bottom, the a and b parameters were not different for the 15 versus $25 \mathrm{~cm}$ structures at $p=0.160$ and $p=0.757$, respectively (table 2).

Because of this lack of significant difference, one equation could be used to represent these combinations of treatments. Thus, for 15 to $25 \mathrm{~cm}$ structures with the $\mathrm{V}$-notch weir placed at any of these three locations, the appropriate weir equation was:

$$
\mathrm{Q}=\mathrm{aH} \mathrm{H}^{\mathrm{b}}=0.011 \mathrm{H}^{2.28}
$$

where

$\mathrm{Q}=$ flow rate $(\mathrm{L} / \mathrm{s})$ and

$\mathrm{H}=$ flow depth above the weir crest $(\mathrm{cm})$.

The coefficient of determination $\left(\mathrm{R}^{2}\right)$ of this model was 0.992 with a standard error of the estimate of 0.135 . The standard deviation of the measured flow rate for each combination of weir height and structure size ranged from $0.1 \%$ and $2.9 \%$ of the mean for that combination. For application purposes, the U.S. customary units form of this equation is:

$$
\mathrm{Q}=\mathrm{aH}^{\mathrm{b}}=1.44 \mathrm{H}^{2.28}
$$


Table 1. Statistical comparison and parameter estimates of stainless steel-edged $V$-notch weir calibration parameters for 15 or $25 \mathrm{~cm}$ control structures when comparing a given control structure size across the three weir placements $(0,48,97 \mathrm{~cm})$.

\begin{tabular}{|c|c|c|c|}
\hline Parameter & Structure size & $\begin{array}{l}\text { P-values when comparing across the } \\
\text { three weir placements }(0,48,97 \mathrm{~cm})\end{array}$ & Parameter mean \pm standard deviation for the three weir placements \\
\hline \multirow{6}{*}{ a parameter } & \multirow{3}{*}{$15 \mathrm{~cm}$ structure } & \multirow{3}{*}{$p=0.126$} & V-notch weir placed at bottom (crest at $12 \mathrm{~cm})$ \\
\hline & & & $48 \mathrm{~cm}$ of stop logs \\
\hline & & & $97 \mathrm{~cm}$ of stop logs \\
\hline & \multirow{3}{*}{$25 \mathrm{~cm}$ structure } & \multirow{3}{*}{$p=0.061$} & V-notch weir placed at bottom (crest at $12 \mathrm{~cm})$ \\
\hline & & & $48 \mathrm{~cm}$ of stop logs \\
\hline & & & $97 \mathrm{~cm}$ of stop logs \\
\hline \multirow{6}{*}{ b parameter } & \multirow{3}{*}{$15 \mathrm{~cm}$ structure } & \multirow{3}{*}{$p=0.457$} & V-notch weir placed at bottom (crest at $12 \mathrm{~cm}$ ) \\
\hline & & & $48 \mathrm{~cm}$ of stop logs \\
\hline & & & $97 \mathrm{~cm}$ of stop logs \\
\hline & \multirow{3}{*}{$25 \mathrm{~cm}$ structure } & \multirow{3}{*}{$p=0.699$} & V-notch weir placed at bottom (crest at $12 \mathrm{~cm}$ ) \\
\hline & & & $48 \mathrm{~cm}$ of stop logs \\
\hline & & & $97 \mathrm{~cm}$ of stop logs \\
\hline
\end{tabular}

Table 2. Statistical comparison and parameter estimates of stainless steel-edged $\mathrm{V}$-notch weir calibration parameters for three weir placements $(0,48,97 \mathrm{~cm})$ when comparing a given weir placement across the two control structure sizes $(15$ or $25 \mathrm{~cm})$.

\begin{tabular}{|c|c|c|c|}
\hline & Weir placement & $\begin{array}{l}\text { P-values when comparing across the } \\
\text { two structure sizes }(15 \text { and } 25 \mathrm{~cm})\end{array}$ & $\begin{array}{l}\text { Parameter mean } \pm \text { standard deviation for the two control } \\
\text { structure sizes }\end{array}$ \\
\hline \multirow{3}{*}{ a parameter } & $\begin{array}{l}\text { V-notch weir placed at bottom } \\
\text { (crest at } 12 \mathrm{~cm} \text { ) }\end{array}$ & $p=0.160$ & $\begin{array}{ll}15 \mathrm{~cm} \text { structure } & 0.015 \pm 0.0014 \\
25 \mathrm{~cm} \text { structure } & 0.010 \pm 0.0043 \\
\end{array}$ \\
\hline & $48 \mathrm{~cm}$ of stop logs & $p=0.449$ & $\begin{array}{l}15 \mathrm{~cm} \text { structure } \\
25 \mathrm{~cm} \text { structure }\end{array}$ \\
\hline & $97 \mathrm{~cm}$ of stop logs & $p=0.097$ & $\begin{array}{l}15 \mathrm{~cm} \text { structure } \\
25 \mathrm{~cm} \text { structure }\end{array}$ \\
\hline \multirow{3}{*}{ b parameter } & $\begin{array}{l}\text { V-notch weir placed at bottom } \\
\text { (crest at } 12 \mathrm{~cm} \text { ) }\end{array}$ & $p=0.757$ & $\begin{array}{l}15 \mathrm{~cm} \text { structure } \\
25 \mathrm{~cm} \text { structure }\end{array}$ \\
\hline & $48 \mathrm{~cm}$ of stop logs & $p=0.069$ & $\begin{array}{l}15 \mathrm{~cm} \text { structure } \\
25 \mathrm{~cm} \text { structure }\end{array}$ \\
\hline & $97 \mathrm{~cm}$ of stop logs & $p=0.298$ & $\begin{array}{l}15 \mathrm{~cm} \text { structure } \\
25 \mathrm{~cm} \text { structure }\end{array}$ \\
\hline
\end{tabular}

where

$\mathrm{Q}=$ flow rate $(\mathrm{gpm})$ and

$\mathrm{H}=$ flow depth above the weir crest (in).

Once the depth of water is greater than $16.5 \mathrm{~cm}$ (the depth of the V; fig. 1), a compound weir equation should be used by combining equation 8 and the appropriate set of previously described equations (either eqs. 1 and 2 or eqs. 3 and 4). Since subsurface drainage water being routed through these structures tends to have low turbulence and low water surface disturbance, field applications of these equations are generally appropriate.

Calibration of any weir is always recommended for individual applications. However, equation 8 could be generalized to a combination of structure sizes and crest height placements. This model was very similar to the standard form of the weir equation for a $45^{\circ} \mathrm{V}$-notch weir [eq. 5: USGS (1982); e.g., the solid black and solid gray lines in fig. 4]. A given depth of water in the $\mathrm{V}$ (that is, a given nappe) in this new stainless steel-edged stop log resulted in

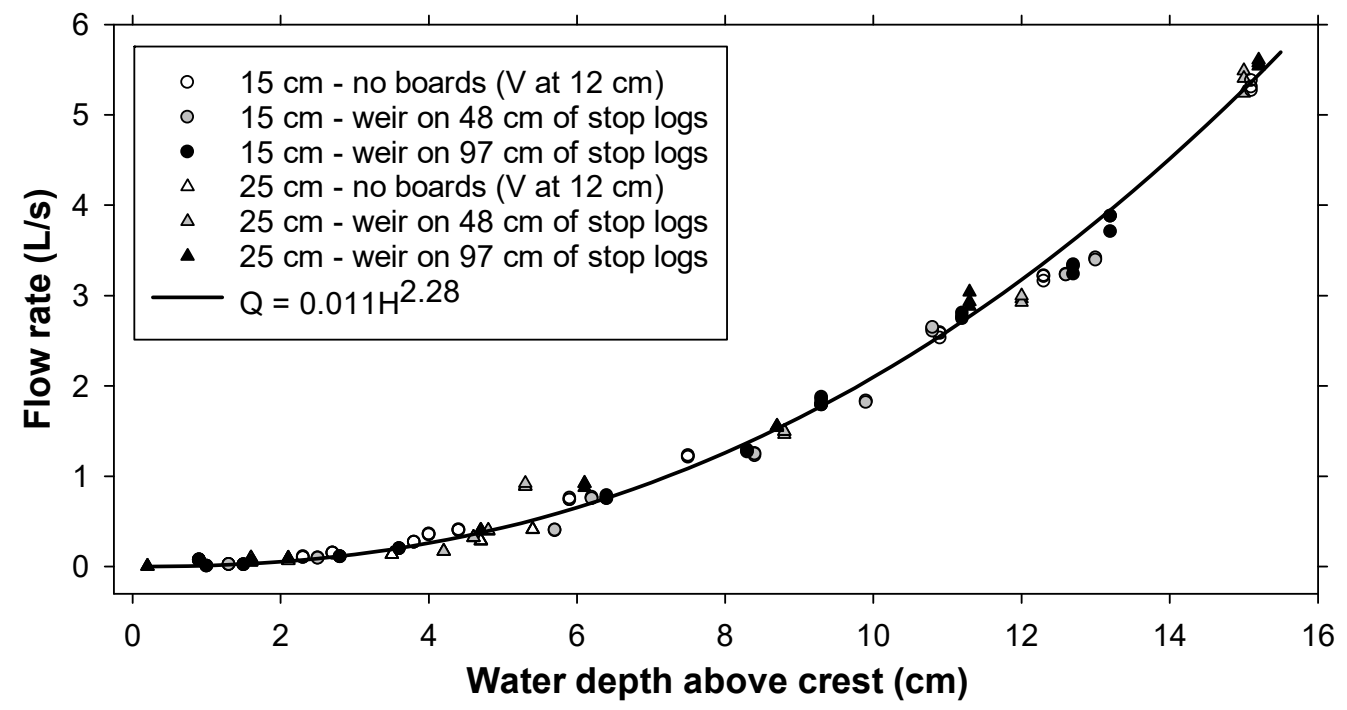

Figure 3. Stainless steel-edged $V$-notch weir calibration for 15 and $25 \mathrm{~cm}$ inline water level control structures with the weir placed on 0 , (structure bottom, no other stop log boards), 48, or $97 \mathrm{~cm}$ of stop logs shown with the corresponding equation 8. 


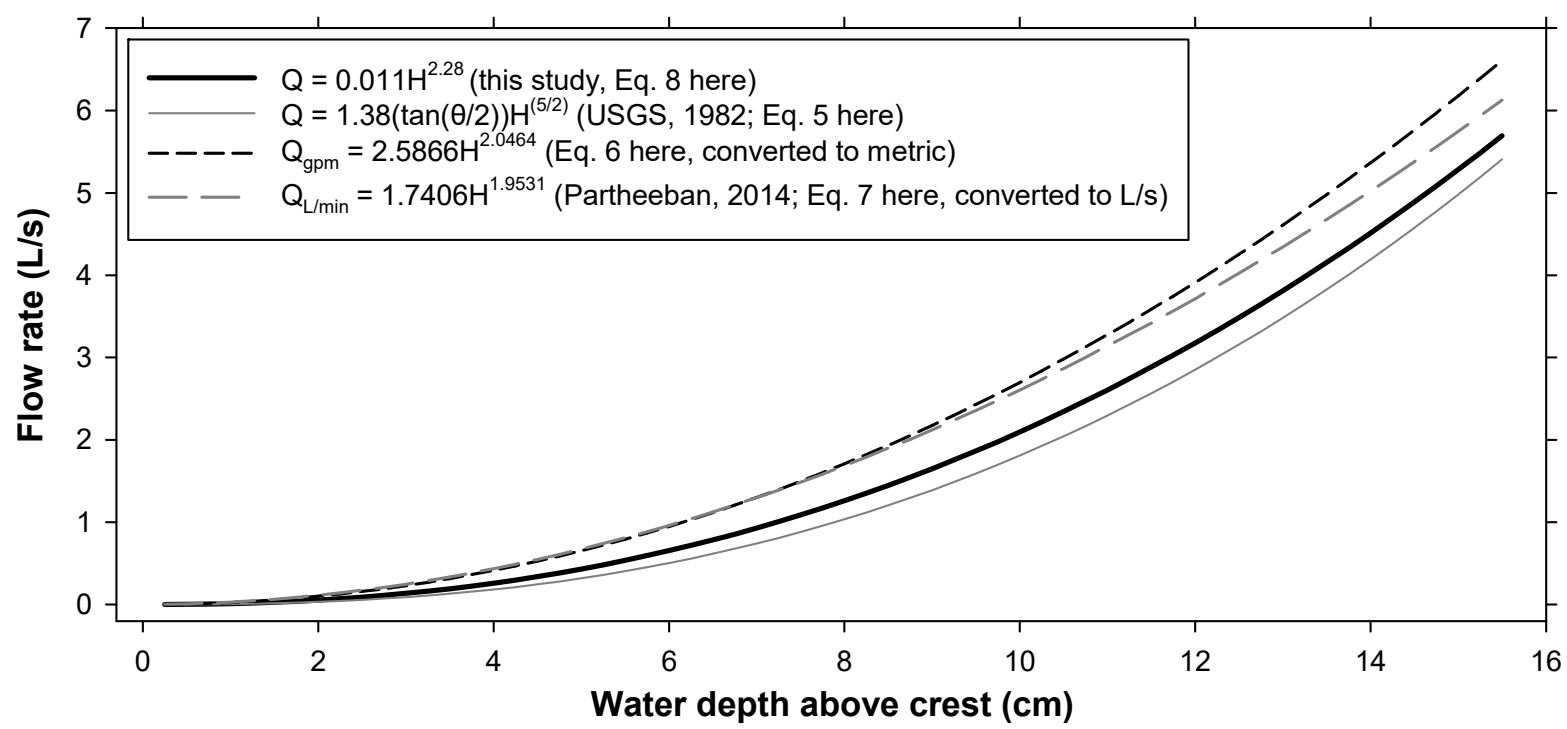

Figure 4. Stainless steel-edged V-notch weir equation developed here (eq. 8) versus the standard form of the equation (USGS, 1982; eq. 5) and two equations formerly developed for the $\mathrm{V}$-notch weir stop logs without the stainless steel front plate (eqs. 6 and 7 ). The maximum flow depth for which equation 8 is valid by itself is $16.5 \mathrm{~cm}$ per the depth of the $\mathrm{V}$ in figure 1 . Equation 7 as originally published is valid within the 0.083 to $2.5 \mathrm{~L} / \mathrm{s}$ range.

a lower flow rate compared to the similar V-notch weir stop logs without the metal front edge (e.g., the solid black versus both dashed lines in fig. 4). The $1^{\circ}$ angle difference between the slightly wider angle of the old V-notch weir stop log ( $46^{\circ}$ angle) and the new $45^{\circ}$ stainless steel-fronted stop log may account for some of this difference.

\section{CONCLUSION}

There was no difference in the stainless steel-edged Vnotch weir stop log flow equations for the two sizes of inline water level control structures nor was a there a difference in the equation for different height placements of the weir stop $\log$ within the structures. In-house calibration of any weir is highly suggested for specific individual applications, but the equation presented here can be used for stainless steel-edged V-notch weir stop logs manufactured for 15 and $25 \mathrm{~cm}$ inline water level control structures. Accurate and dependable flow measurements to assess effectiveness of drainage conservation practices will continue to remain important, and it is hoped this new weir calibration equation can aid in future conservation efforts.

\section{ACKNOWLEDGEMENTS}

This work was partially funded by USDA NIFA HATCH projects ILLU-802-925 and ILLU-741-323. Thanks to Mr. Brian Didonato for the computer-aided design illustrations.

\section{Author Contributions}

This work was done collaboratively as a lab group: all student authors plus R. Cooke helped with data collection; R. Christianson performed the data analysis with statistical advice from A. Lipka; L. Christianson wrote the article; and L. Christianson and R. Cooke were the lab group leaders co- ordinating the project. Student contributors were ordered alphabetically by last name in the author line.

\section{REFERENCES}

Chun, J. A., \& Cooke, R. A. (2008). Technical note: Calibrating agridrain water level control structures using generalized weir and orifice equations. Appl. Eng. Agric., 24(5), 595-602. https://doi.org/10.13031/2013.25274

Evans, R. O., Wayne, S. R., \& Wendell, G. J. (1995). Controlled versus conventional drainage effects on water quality. J. Irrig. Drain. Eng., 121(4), 271-276. https://doi.org/10.1061/(ASCE)0733-9437(1995)121:4(271)

Haan, C. T., Barfield, B. J., \& Hayes, J. C. (1994). Design hydrology and sedimentology for small catchments. San Diego, CA: Academic Press.

Novak, P., \& Cabelka, J. (1981). Models in hydraulic engineering. London, U.K.: Pitman Publ.

Partheeban, C. (2014). Demonstrating the effectiveness of nitratenitrogen removal of denitrifying bioreactors in South Dakota for improved drainage water management. MS thesis. Brookings: South Dakota State University, Agricultural and Biosystems Engineering Department.

Randall, G. W., \& Goss, M. J. (2008). Ch 6: Nitrate losses to surface water through subsurface, tile drainage. In J. L. Hatfield, $\&$ R. F. Follett (Eds.), Nitrogen in the environment: Sources, problems, and management (2nd. ed., pp. 145-175). San Diego, CA: Elsevier Science. https://doi.org/10.1016/B978-0-12374347-3.00006-8

Scharf, P. (2015). Managing nitrogen in crop production. Madison, WI: ACSESS Publ. https://doi.org/10.2134/2015.managingnitrogen.c2

Skaggs, R. W., \& Van Schilfgaarde, J. (1999). Drainage for agriculture. Monograph No. 38. Madison, WI: ASA.

USGS. (1982). Measurement and computation of streamflow: Vol. 2. Computation of discharge (Geological Survey Water-Supply Paper 2175). Washington, DC: USGS. 